\title{
Psychological Empowerment and Commitments of Changes on the Civitas Academica of Universitas Negeri Padang
}

\author{
Rindang $\mathrm{Ayu}^{1 *}{ }^{*}$, Rahayu Hardianti Utami ${ }^{1}$, Nurmina $^{1}$ \\ ${ }^{1}$ Department of Psychology of Universitas Negeri Padang, Indonesia \\ *Corresponding author. Email: rindang.ayu17@gmail.com
}

\begin{abstract}
In this globalization era, the workplace should change and develop continuously. BLU (Badan Layanan Umum) as a new regulation makes a change in the organization entirely, including work standard, financial procedures, organizational structural, and many more. If the changes are not made, then this will have an impact on individuals (lecture) and organizations. For lecture, they do not get remuneration and cannot develop their carier in organization. For organizations, this will make the organization (institution) lag behind other institutions. For those reasons, to make an organizational change becomes effective, employee's commitment is highly needed for it. A commitment to change as a bound between employees to the organizations which help to make a change become successful. The sampling technique is non random sampling and the questionnaire was distributed to 250 lecturers at State Universty in Padang. Correlation test is used to see the relationship between pychological empowerment and commitment to change. The results of this study show there is a relationship between psychological empowerment and commitment to organizational change. Lecturer as the academic community in university aside has obligation to the needs of "Tridharma Perguruan Tinggi", they also feel the importance of career development as part of selfdevelopment.
\end{abstract}

Keywords: Psychological empowerment, commitment to organizational change, lecturer

\section{INTRODUCTION}

In this era of globalization, the world of work is required to changes and develops continuously. According to Chonko, Jones, Roberts, \& Dubinsky (2002), changes made by these organizations are the result of responses to events that occur within the organization due to the increasingly competitive environment. Organizational changes are something that continues to happen now and in the future, so these changes cannot be avoided (Jex \& Britt, 2008).

Changes do not only come from the environment (external), but also can occur from within the company itself (internal), such as a decrease in profits, the competence of employees who go down, the growth of the company itself, the opportunity to develop the company's business, the discovery of new innovations within the company, and policies carried out by management company (Madsen, Miller, \& John, 2005).

These matters require organizations to make changes in order to survive and remain competitive (Susanto, 2008). Changes made by a company are not always successful. Devos, in Nordin (2011), notes that failure of changes made by an organization is caused by a lack of commitment and motivation of employees. For this reason, in order to make changes in the organization run well, it is very necessary for the employees' commitment to these changes (Vakola \& Nikolaou, 2005).

For an organization, changes are not an easy thing to accept because basically, every organization is conservative that is rejecting changes (Robbins, 2003). Many aspects must be considered so that changes can work effectively, not in vain or not get rejected. In organizations that are under the government, changes are a difficult thing to accept because generally, employees are familiar with the pattern and demands of the same work from year to year. This also happened at one of the state universities in West Sumatra, namely Universitas Negeri Padang.

Since 2016, many changes have been made by Universitas Negeri Padang, both in terms of work demands, financial procedures, organizational structures, etc. For this reason, researchers want to see whether the lecturers and employees who feel the changes have a commitment to the changes made or not. This is useful so that these changes can run effectively and successfully. The important thing that can affect employee 
commitment to changes is motivation. One motivational construct that has an effect on changes according to (Parish, 2008) is psychological empowerment.

According to Sprietzer (1995), psychological empowerment is a construct of motivation manifested in four cognitions, namely meaning, competence, determination (self-determination) and impact. These four cognitions together reflect an active orientation towards the role of work. Active orientation means the orientation in which an individual wants and feels capable of forming their own work in their role or context in their work. For this reason, the researcher wants to see the relationship between psychological empowerment and commitment to changes in the academic community at Universitas Negeri Padang.

Organizational changes can be a core of changes aspect of an organization. This core aspect includes the structure, technology, culture, leadership, goals or members of an organization (Mills, Dye, \& Mills, 2009). Daft (2007) defines organizational changes as the adoption of a new idea or behaviour carried out by the organization.

Kreitner \& Kinicki (2004) divide the two things that cause organizational change.

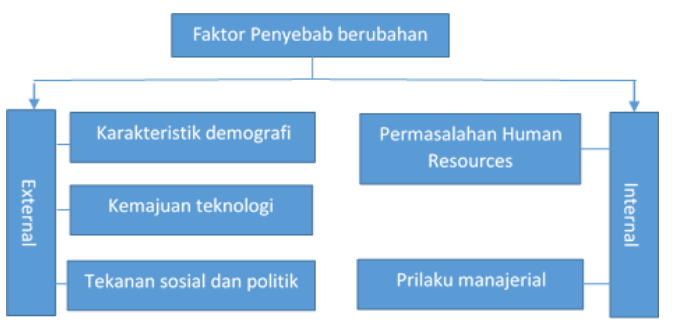

Figure 1. Causes of Changes Factors

According to Armenakis, A. A, Harris and Mossholer (1993), there are two factors that determine the success of organizational changes, namely: (1). Readiness for organizational changes, (2). Commitment to organizational changes (Herscovith \& Meyer, 2002). When changes occur, the commitment of employees who carry out the changes will make the success of the changes that will have an impact on work performance, both financially and non-financially in the organization. (Cadwallader and Busch 2008). Commitment to changes is a form of commitment that is widely used in theoretical discussions of organizational changes models that provide a mindset to make individuals take actions that are relevant to one or more targets (Herscovith \& Meyer, 2002).

Three dimensions of commitment to changes (He Herscovith and Meyer 2002) are as follows:

2. Affective commitment

Affective commitment is the desire of individuals to support changes because they feel confident that the changes can have a good impact on the company.

\section{Continuance commitment}

Continuous commitment is a tendency to make changes that aim to avoid losses that will be caused if you do not make changes.

4. Normative commitment

Normative commitment reflects an individual's obligation to support changes.

According to Chonger and Kanungo (1988), in addition to commitment, leaders must also be able to provide motivation to increase feelings of self-efficacy to workers in order to enable these workers to be able to complete their work more effectively and efficiently or better known as empowerment. Thomas and Velthouse (1990) define empowerment as one form of assignment that involves intrinsic motivation which is manifested in four cognitive dimensions, namely meaningfulness, competence, choice and impact. Spreitzer (1995) states that there are two perspectives in empowerment, where the first focus is cultural social conditions that can support empowerment in the work environment (structural empowerment) and the second is the psychological experience of employees towards empowerment (psychological empowerment). Furthermore, Spreitzer (1995) states that psychological empowerment is a motivation construct that is manifested in four aspects of cognition, namely meaning, competence, self-determination, and impact. These four cognitions together reflect the active (not passive) orientation of the work role. Active orientation means orientation where someone wants and feels capable of forming his or her own role in the context of his or her work.

\section{METHOD}

This research was a quantitative research where the data generated was in the form of numbers and was processed using statistical calculations. The analysis that was used is correlational, which aims to see the relationship between two or more variables.

The population in this study was the academic community of the Universitas Negeri Padang. The characteristics of the sample in this study were lecturers at Universitas Negeri Padang who had a minimum work period of 2 years and were permanent lecturers. The reason for determining the sample was because it was assumed that the permanent lecturer and had worked for two years felt there were organizational changes. The sampling technique used was non-random sampling, where the subject who were the participants of the study was the subject that was available at that time and which corresponds to the general characteristics of the research subject (Kumar, 2005). The number of respondents for this research try out was 40 people. For data collection, the sample used was 250 people. 
The tool used by researchers in taking this research data was a questionnaire. This questionnaire measures 2 variables to be examined, namely psychological empowerment and commitment to organizational changes.

Table 1. Psychological Empowerment Measurement

\begin{tabular}{|c|c|c|}
\hline Dimensions & $\begin{array}{l}\text { Item } \\
\text { Number }\end{array}$ & $\begin{array}{l}\text { Example of } \\
\text { Items }\end{array}$ \\
\hline Competency & $1,9,11,15$ & $\begin{array}{l}\text { I am sure that I } \\
\text { have a good } \\
\text { ability to be able } \\
\text { to produce the } \\
\text { performance. }\end{array}$ \\
\hline Significance & $2,5,8,13$ & $\begin{array}{l}\text { My work means a } \\
\text { lot to me. }\end{array}$ \\
\hline Determination & $3,7,10,16$ & $\begin{array}{l}\text { I have the } \\
\text { authority to } \\
\text { determine how I } \\
\text { work }\end{array}$ \\
\hline Impact & $4,6,12,14$ & $\begin{array}{l}\text { I have a big } \\
\text { influence on what } \\
\text { happens in my } \\
\text { department }\end{array}$ \\
\hline
\end{tabular}

Table 2. Measuring Commitments on Changing

\begin{tabular}{lll}
\hline Dimensions of & $\begin{array}{l}\text { Item } \\
\text { Numbers }\end{array}$ & Example of Items \\
\hline Affective & $1,4,7 *, 10$, & I believe these \\
Commitments & $13 *, 16^{*}$ & $\begin{array}{l}\text { changes important } \\
\text { Continuance }\end{array}$ \\
$\begin{array}{l}\text { Commitment } \\
14,17 * 8,11,\end{array}$ & $\begin{array}{l}\text { I must follow the } \\
\text { changes in the } \\
\text { organization of }\end{array}$ \\
$\begin{array}{l}\text { Normative } \\
\text { Commitments }\end{array}$ & $3,6,9 *, 12, \begin{array}{l}\text { I feel obliged to } \\
\text { carry out this } \\
\text { changes }\end{array}$ \\
\hline
\end{tabular}

Note: $a^{*}=$ unfavorable item

The stage of this research is divided into several stages:

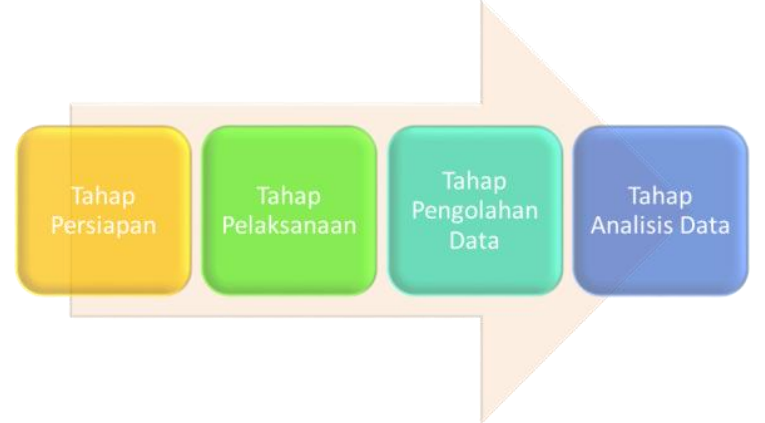

Figure 2. Stages of Research

Data processing in this study used statistical calculations with SPSS 22.0. SPSS was used to see the validity and reliability of measuring instruments. In addition, this application is also used to measure the correlation between psychological empowerment and commitment to organizational changes by using Pearson, which aims to examine the relationship between two or more variables.

\section{RESULTS AND DISCUSSION}

Table 3. Descriptions of each variable

\begin{tabular}{lcc}
\hline Variable & $\begin{array}{l}\text { Commitment } \\
\text { Organization } \\
\text { Changes }\end{array}$ & $\begin{array}{c}\text { Psychological } \\
\text { Empowerment }\end{array}$ \\
\hline $\mathrm{N}$ & 182 & 182 \\
Maximum & 102 & 96 \\
Minimum & 60 & 59 \\
Mean & 82.71 & 78.26 \\
SD & 7.98 & 7.76 \\
\hline
\end{tabular}

To answer the research question about whether there is a relationship between psychological empowerment and commitment to organizational changes, the researcher conducted a correlation analysis by looking at the significance value of processing research data. Here are the results of correlation analysis between variables which were obtained:

Table 4. Results of correlation test on psychological empowerment and commitment to organizational changes

\begin{tabular}{lllll}
\hline & C2C & PE & sig & $n$ \\
\hline $\begin{array}{l}\text { Psychological } \\
\text { Empowerment } \\
(\mathrm{PE})\end{array}$ & $0: 15 *$ & & & 182 \\
\hline Commitment & 1 & $0.15 *$ & $0,038 *$ & 182 \\
Organizational & & & & \\
Changes \\
$(\mathrm{C} 2 \mathrm{C})$
\end{tabular}
empowerment, the higher the value of commitment of organizational changes which someone has. The results of this study are supported by Gustafson (2012) research which states that one of the important constructs that influence the success of an organization in making changes is psychological empowerment. In addition, research from Jha (2011) also shows that psychological empowerment has an influence on organizational commitment in making changes.

Based on the results of the study, it can be seen that the lecturers at Universitas Negeri Padang are committed to the made organizational changes. This is illustrated by three dimensions of organizational changes commitment, namely commitment to affective changes, commitment to continuous changes, and commitment to normative changes. In the affective changes commitment, it can be seen the desire of the lecturers to support changes because they feel confident that these changes will have a good impact on their institutions. In the commitment to continuous change, it can be seen that there is a tendency to make changes aimed at avoiding losses that will be 
caused if changes are not made. In the normative changes commitment, it can be seen that there is a duty of lecturers to support changes made by institutions.

\section{CONCLUSION}

There is a positive and significant relationship between psychological empowerment and commitment to organizational changes

\section{REFERENCES}

Armenakis, A. A., Harris S. G., \& Mosseholder, K. W. (1993). Creating readiness for organizational change. Human Relation, 46, 681-703.

Armenakis, A. A., \& Harris, S. G. (2002). Crafting a change message to create

transformational readiness. Journal of Organizational Change Management, 15, 169-183.

Chonko, L.B., Jones, E., Roberts, J.A., \& Dubinsky, A. J. (2002). The role of Environmental

Chonger, J. A., \& Kanungo, R. N. (1988), The empowerment process: Integrating

theory and practice. Academy of Management Review, $13,471-482$.

Daft, R. L. (2007). Understanding the Theory and Design of Organizations. $\mathrm{OH}$ : Thomson.

Kreitner, \& Kinicki. (2004). Organizational Behavior (6th ed). New York: Mc Graw Hill.

Kumar, R. (2005). Research methodology: A step-by-step guide for beginners $\left(2^{\text {nd }}\right.$ ed). London: SAGE Publications Ltd.

Madsen, R.S., Miller, Duane \& John, R C. (2005). Readiness for organizational change: Do organizational commitment and social relationships in the workplace make a difference?. Western Academy of Management: Las Vegas

Meyer, J.P., Allen, N.J. (1991). Commitment in the workplace: Theory, reasearch, And application. London: Sage Publication.

Meyer, J.p., Allen, N.J., \& Smith, C.A. (1993). Commitment to organizations and occupations: extentions: extention and test of three-component coonceptulization. Journal of Applied Psychology, 89, 6, 991-1007.

Meyer, J.P. \& Herscovitch, L. (2001). Commitment in the workplace: toward general model. Human Resources Management Review, 11, 299-326.

Mills, Jean Helms., Dye, Kelly., and Mills, Albert.J. (2009). Understanding Organizational Change. New York: Routledge.

Nordin, Norshidah. (2011). The influence of emotional intelligence, leadership behaviour and organizational commitment on organizational readiness for change in higher learing institution. Procedia - Social Behavioral Sciences 29, 129 138.
Parish, J. T., Cadwallader, S., \& Busch, P. (2008). Want to, need to, ought to: Employee commitment to organizational change. Journal of Organizational Change Management, 21 (1) , 32-52.

Robbins, Stephen.P., (2003). Organizational Behavior, (10th ed). New Jersey: Person Education International.

Seniati, L., Yulianto, S., Setiadi, B.N. (2009). Psikologi Eksperimen. Indonesia:

PT Indeks.

Shah, N. (2011). A study of the relationship between organizational justice and employee readiness for change. Journal of Enterprise Information Management,24 (3), 224-236.

Spreitzer, G.M. 91995). Psychological empowerment in the workpalce: Dimensions, measurement and validation. Academy of Management Journal, 38, 1442-1465

Stjernen, A. (2009). Perceived Fairness and Resistance to Organizational Change in Relation to ChangeCommitment. University of Oslo. Disertasi

Susanto, A.B. (2008). Organizational readiness for change: A case study on change readiness in a manufacturing company in Indonesia. International Journal of

Management Perspectives

Thomas, K.W., \& Velthouse, B.A.(1990). Cognitive elements of empowerment: An 'interperative' model of intinsic task motivation. Academy of Management Review, 15, 666-681

Thomas, K.W., \& Velthouse, B.A.(1990). Cognitive elements of empowerment: An 'interperative' model of intinsic task motivation. Academy of Management Review, 15, 666-681

Vakola, M., \& Nikolaou, I. (2005). Attitudes towards organizational change: What is the role of employees's stress and commitment? Employee Relation, 27, 160-174 